\title{
Reply to a comment by Franco Gabrielli and Daniela Di Bucci: "Communicating earthquake risk to the public: the trial of the 'L'Aquila Seven'"
}

\author{
David E. Alexander
}

Received: 20 June 2014/ Accepted: 10 July 2014/Published online: 23 July 2014

(C) The Author(s) 2014. This article is published with open access at Springerlink.com

\begin{abstract}
In this comment, I reply to criticisms of my article on the trial of seven defendants accused of providing the public with misleading information shortly before the L'Aquila, central Italy, earthquake of 6 April 2009.
\end{abstract}

Keywords Earthquake - Disaster - Warning - Public information - Legal proceedings · Italy

The trial of seven defendants after the L'Aquila earthquake of 2009 is a highly controversial issue and is likely to remain so for a considerable time into the future (Scolobig et al. 2014). I thank Gabrielli and Di Bucci (2014) for their comment on my article (Alexander 2014) and welcome the opportunity to debate this topic and defend my position on it.

Regarding the denigration of the term "L'Aquila trial" as 'so-called', I believe that this epithet is a good shorthand way of referring to the process. However, one thing it does not do is to convey the endless subtleties, numerous facets and abundant opportunities for multiple interpretations of this event.

Regarding comments about "untrue and inexact statements, misleading reasoning processes" and "contradictions, inaccuracies and false statements throughout the text [of my article]", I disagree with and strongly dispute all such judgements. To begin with, the observation that "most of [my] references are not peer reviewed" belies the fact that many of the best and most insightful comments on the L'Aquila trial were not made in peerreviewed publications. My aim was not to legitimise my comments with the device of peer

D. E. Alexander $(\bowtie)$

University College London, London, UK

e-mail: david.alexander@ucl.ac.uk 
review (please note, however, that my article was very substantially peer reviewed!), but to get at the truth behind the trial and examine its implications.

Another observation made by Gabrielli and Di Bucci is that "the point of view of the defendants is completely neglected". First, the weaknesses in the prosecution case are brought out on page 1,170 of my article. Secondly, it was hardly necessary to promote the case for the defence, given the ability of the defendants to state their own case. For example, Enzo Boschi published his personal justification in Science magazine (Boschi 2013), which, however, did not allow the International Seismic Safety Organisation to publish a rejoinder. This is hardly surprising, given that the American Association for the Advancement of Science so substantially overreached itself with the petition in favour of the defendants and its open letter to the President of Italy. AAAS is the publisher of Science.

According to Gabrielli and Di Bucci, "the defence was based on scientific reports and on depositions provided by top scientists". That may be so, but the prosecution case was put together at least as well, with similar depositions. Moreover, there are some inescapable facts. The first of these is that the Commissione Grandi Rischi (CGR) unequivocally stated that an earthquake sequence would not be punctuated with a major shock (L'Espresso 2009), even though its members were meeting in the very city where this had happened, in 1703, with major loss of life. The overwhelming reaction of the external commentators was that "science is on trial", and this view has persisted (Elliott 2013). It was manifestly not the case. The seven defendants were not tried for their role or ability as scientists. In Italy, as in other countries, it is perfectly possible for scientists to have additional roles that utilise their expertise and judgement. In this context, if controversial decisions have to be taken, I see something of a contradiction in the role of the CGR as an independent body that is nevertheless part of the Dipartimento Nazionale di Protezione Civile. This implies a lack of adequate definition, or at least separation, of responsibilities. However, regardless of this, the CGR behaved impeccably in the Pollino earthquake swarm of 2012 and the Garfagnana-Lunigiana seismic sequence of 2013-2014 (Paparella 2013, p. 61). Clearly, something about living with seismic risk had been learnt from the L'Aquila experience.

Regarding misstatement of the duration of the trial, this depends on how the beginning and ending are defined, as all trials involve preparatory work and this one was no exception. In any case, the length of the trial was not particularly germane to its outcome.

As much of the controversy about the L'Aquila earthquake concerns science, its use and its misuse, it is interesting to see my methodology called into question. Gabrielli and Di Bucci state: "we wonder why the motivations for the prosecution are taken from a newspaper... and not from the primary source, i.e. the judge's sentence that is publicly available". In fact, the motivation for the sentence had not been written when the article was submitted, but was made available during the latter stages of processing the manuscript. However, the publication of this 800-page document (Tribunale di L'Aquila 2012) did not suggest to me that any significant changes were required in my interpretations. As one can see from the reference list of my article, I took information from a wide variety of sources, not merely newspapers.

As can be deduced from both my article and Gabrielli's and Di Bucci's reply, there is some confusion about exactly who were the plaintiffs in the trial. The official report of the judges (Tribunale di L'Aquila 2012) lists the original plaintiffs as acting on behalf of 37 people who died and five who were injured. This was reduced at the start of the trial to 30 of the dead and four of the injured. The provisions for compensation 
determined at the conclusion of the trial are complex, but they refer to 31 victims of the earthquake. ${ }^{1}$

According to Gabrielli and Di Bucci, "it is reported that the L'Aquila earthquake "damaged about 100,000 buildings", whereas in reality, they were ca. 35,000"-possibly, but that depends on how damage is defined. About twice as many municipalities reported damage as those that were officially classified as damaged. Although it was in their interests to do so, and perhaps to exaggerate the effects of the earthquake, examination of the surrounding municipalities reveals that their level of seismic vulnerability is extremely high. Damage in any strong motion is bound to be excessive. Early estimates (Çelebi et al. 2010 ) indicated that 60,000 buildings may have been visibly damaged and tens of thousands of others required precautionary evacuation.

Regarding video evidence, Dr De Bernadinis did indeed make the statement that the public should relax, go home and have a glass of Montepulciano d'Abruzzo wine. On this basis, the video "went viral" on YouTube. ${ }^{2}$ There is no indication in the video of exactly when De Bernadinis gave the interview, except that the filmed sequence includes views of the meeting, and strongly gives the impression that it was recorded at the conclusion. If this was not the case, then De Bernadinis had absolutely no justification for prejudging the outcome.

Concerning the seismic classification of L'Aquila city, it was not my intention to give the impression that it was established in 1980. However, this year was a turning point, as it came at a key moment in the "Applied Geodynamics Project" (Progetto Finalizzato Geodinamica), which had investigated many aspects of the seismicity of Italy (Sabetta et al. 2001). It is very hard to imagine that there would be a scientific justification for "bending" the high seismicity category around L'Aquila in such a way that left it in the second (moderate) category. Major problems of soft sediments, karstic tunnelling and topographic amplification are present in the city, which also has active faults within its limits. Yet for decades, it was classified as of lower seismicity than the surrounding municipalities. It is therefore significant that during the 2009 earthquake more people died in the collapse of reinforced concrete buildings than in older masonry ones (Alexander and Magni 2013).

The meeting of 31 March 2009 was indeed ostensibly held to examine the seismic phenomena that had been occurring for months in the L'Aquila area. However, as the participants appear not to have made any serious evaluation of these phenomena, and instead made a number of statements that the prosecution and judges felt were unsubstantiated by science, then the written reason (see L'Espresso 2009, p. 1) does not coincide with the real motive for holding the meeting. It is an undeniable fact that public disquiet had been growing since the point at which Giuliani's "prediction" was leaked. At the time, the response to Giuliani and the desire to calm the public clearly dominated the agenda.

In my article, I quoted some pronouncements, from among many, by scientists outside Italy, which clearly demonstrate a lack of understanding of the trial. Certainly, there were those who understood it, but let them all be judged by their words.

\footnotetext{
1 Alloggia Silvana, Bonanni Anna Berardina, Cacioppo Stefania, Carosi Claudia, Ciancarella Elvezia, Cinque Davide, Cinque Matteo, Cora Alessandra, Cora Antonella, Di Bernardo Cinzia, Fioravanti Claudio, Fulcheri Ana Paola, Germinelli Chiara Pia, Germinelli Rosa, Germinelli Giuseppina, Germinelli Micaela, Giugno Francesco, Giugno Luigi, Hamade Hussein, Ianni Franca, Liberati Vezio, Massimino Patrizia, Parisse Maria Paola, Parisse Domenico, Placentino Ilaria, Rambaldi Ilaria, Shain Hisham, Spaziani Claudia, Tomei Paola, Visione Daniela and Vittorini Fabrizia.

2 http://www.youtube.com/watch?v=kLIMHe0NnW8.
} 
I have never asserted that Giuliani could predict earthquakes or that his assertions about enhanced earthquake risk were correct. In an interview with the German press agency Deutsche Welle shortly after the earthquake (cited by, among others, the Italian Minister of Defence when he appeared on national television), I suggested that the question of whether earthquakes could be predicted in the short term was irrelevant to the case. What mattered was whether the capacity existed to respond to the alarm. Other analysts have taken a similar view (e.g. Scolabig et al. 2014). It is an inconvenient fact that Giuliani raised the alarm and a seismic disaster subsequently occurred. One is inclined to attribute this to coincidence rather than scientific prowess, but nevertheless the official response needs to be examined in the light of what could be done, or should have been done to respond to the situation, other than attempt to calm the population and suppress the messenger. Meanwhile, more meticulous and rigorous analyses remain equivocal about the presence or absence of radon anomalies at the time of the earthquake (cf. Quattrocchi et al. 2012, Pitari et al. 2014).

One of the most distasteful aspects of the L'Aquila earthquake aftermath was the attempt to discredit Giuliani on the basis of his position, not his ideas. It would have been easy enough to do so purely on the basis of the latter, but instead, his detractors felt that he had to be belittled. The attempt to do the same with Dr Antonio Ciccozzi, using bibliometry, is equally distasteful. Ciccozzi's (2013) book, The Word of Science (Parola di Scienza), offers 184 pages of insight and reflection on the earthquake, its aftermath and the trial. None of this is diminished by its absence from Scopus. Those who would use bibliometry as a justification should consider some of the critiques of it (e.g. Moustafa 2014).

Lest there be any suspicion of a conspiracy, I would like to point out that the International Seismic Safety Organisation is run by diverse people in diverse parts of the world, not merely L'Aquila, and my membership of it does not preclude me from presenting my own views, which are entirely independent of any 'official line' that ISSO may take, or consensus that it may encourage.

My statement about the actions of civil protection in Paganica is based on reports from reliable eye witnesses and is not intended as any kind of an indictment of the national Department of Civil Protection (DPC), but as a statement about what actually happened. However, although local civil protection authorities acted in this case, the policy and strategy were clearly set nationally. Reassuring advice was given by civil protection representatives, and whether they were DPC employees or not had little bearing in its outcome. I noted (Alexander 2014, p. 1170) that the link between this advice and the culpability of the defendants in the trial was the weakest part of the prosecution's case. It may well be sufficient reason to exonerate the defendants at appeal.

My comments on the reduced role of local and regional authorities in the aftermath were based on personal observation and wide reading. I stand by them. As is so often the case in Italy, the political situation in Abruzzo after the earthquake was undeniably very complex. In a country with a Prime Minister who had gained a reputation for passing laws ad hominem, it should astonish no one if comments are made about the fight for the independence of the judiciary, which has been under attack for many years. When the then Prime Minister passed on to promoting ad aziendam laws on behalf of his own commercial companies, many felt that he had overreached himself (Travaglio 2010). It seems to me quite disingenuous to describe as "frankly astonishing" a view that the trial has political significance, which is something that very many analysts and commentators, both Italian and foreign, have noted (Guarnieri 2013).

The final comments in Gabrielli's and Di Bucci's critique of my article imply that I was trying to arrive at a judgement on the sentence. This is explicitly what I did not set out to 
do, as I made clear at the start of my article. Considering the social, political and cultural referents of the trial is not a matter of trying to judge whether it was fair or unfair, but of understanding the context in which the trial took place, and how that context influenced the decision to prosecute. In my view, some elements of the trial were fair and well justified, others much less so. The final balance awaits the outcome of one or more appeals by the defendants against their sentences.

Open Access This article is distributed under the terms of the Creative Commons Attribution License which permits any use, distribution, and reproduction in any medium, provided the original author(s) and the source are credited.

\section{References}

Alexander DE (2014) Communicating earthquake risk to the public: the trial of the "L'Aquila Seven". Nat Hazards 72:1159-1173

Alexander DE, Magni M (2013) Mortality in the L'Aquila (central Italy) earthquake of 6 April 2009. PLoS Curr Dis $1-26$

Boschi E (2013) L'Aquila's aftershocks shake scientists. Science 341:1451

Çelebi M, Bazzurro P, Chiaraluce L et al (2010) Recorded motions of the 6 April 2009 Mw6.3 L'Aquila, Italy, earthquake and implications for building structural damage: overview. Earthq Spectra 26:651-684

Ciccozzi A (2013) Parola di scienza: Il terremoto dell'Aquila e la Commissione Grandi Rischi, un'analisi antropologica. DeriveApprodi, Rome

Elliott J (2013) Science on trial: the L'Aquila earthquake. Living Ethics 94, Article 16

Gabrielli F, Di Bucci D (2014) Comment on "Communicating earthquake risk to the public: the trial of the “'L'Aquila Seven",”, by David E. Alexander. Natural hazards

Guarnieri C (2013) Courts enforcing political accountability: the role of criminal justice in Italy. In: Kapiszewski D, Silverstein G, Kagan RA (eds) Consequential courts: judicial roles in global perspective. Cambridge University Press, Cambridge, pp 163-180

L'Espresso (2009) Verbale riunione della Commissione Grandi Rischi, L'Aquila, 31 marzo 2009. L'Espresso, Rome, 17 April 2009

Moustafa K (2014) The disaster of the impact factor. Sci Eng Ethics (awaiting final pagination)

Paparella F (2013) La condanna dell'Aquila: cattiva giustizia, cattiva scienza o negligenza? Ithaca, Viaggio nella Scienza I:51-62

Pitari G, Coppari E, De Luca N, Di Carlo P (2014) Observations and box model analysis of radon-222 in the atmospheric surface layer at L'Aquila, Italy: March 2009 case study. Environ Earth Sci 71:2353-2359

Quattrocchi F, Pizzi A, Gori S, Boncio P, Voltattorni N, Sciarra A (2012) The contribution of fluid geochemistry to define the structural patterns of the 2009 L'Aquila seismic source. Italian J Geosci 131:448-457

Sabetta F, Bramerini F, Lo Presti T, Lucantoni A (2001) La nuova carta di riclassificazione sismica. Ingegneria Sismica 1:7-9

Scolobig A, Mechler R, Komendantova N, Liu W, Schröter D, Patt A (2014) The co-production of scientific advice and decision making under uncertainty: lessons from the 2009 L'Aquila earthquake, Italy. GRF Davos Planet@Risk 2:71-76

Travaglio M (2010) Ad personam. Chiarelettere, Milan

Tribunale di L'Aquila (2012) Sentenza nella causa penale contro Barberi Franco, De Bernadinis Bernardo, Boschi Enzo, Selvaggi Giulio, Calvi Gian Michele, Eva Claudio, Dolce Mauro. Tribunale di L'Aquila, L'Aquila, Italy 